\title{
RECENT LEGISLATION
}

\section{Tackling Vulnerability to Labour Exploitation through Regulation: The Case of Migrant Fishermen in Ireland}

\author{
Acceptance date 26 June 2017
}

\section{INTRODUCTION}

In November 2015, the Guardian newspaper reported severe and widespread abuse of migrant workers within the Irish fishing industry. ${ }^{1}$ The patterns of exploitation identified by the team of journalists mirror findings across other jurisdictions and sectors relating to the labour conditions of migrant workers. ${ }^{2}$ They included workers being confined to vessels unless given permission to go on land; receiving no proper rest days; and being paid less than half the Irish minimum wage. ${ }^{3}$

The Guardian reports led to intense media coverage and pressure on the Irish Government, prompting the immediate formation of a Task Force and ultimately the adoption of an 'Atypical Working Scheme for non-EEA crew in the Fishing Fleet' ${ }^{4}$ which sought to formalise and regularise the workers' immigration and employment status. This is not a legislative measure as such: in the Irish system, atypical working schemes are administrative measures emanating from the Irish Naturalisation and Immigration Service (within the Department of Justice and Equality). Atypical working schemes provide for permits for 'atypical, short term

\footnotetext{
${ }^{1 ' R e v e a l e d: ~ T r a f f i c k e d ~ M i g r a n t ~ W o r k e r s ~ A b u s e d ~ i n ~ I r i s h ~ F i s h i n g ~ I n d u s t r y ', ~ G u a r d i a n, ~} 2$ November 2015, https://www.theguardian.com/global-development/2015/nov/02/revealed-trafficked-migrant-workers-abused-in-irish-fishing-industry (last accessed 13 June 2016).

${ }^{2}$ In respect of the fishing sector, see International Labour Office, Caught at Sea: Forced Labour and Trafficking in Fisheries (Geneva: ILO, 2013); C. Stringer, S. Hughes, D. Whittaker, N. Haworth and G. Simmons, 'Labour Standards and Regulation in Global Value Chains: The Case of the New Zealand Fishing Industry' (2016) 48 Environment and Planning 1910. More generally, see International Labour Office, Promoting Fair Migration: General Survey Concerning the Migrant Workers Instruments (Report of the Committee of Experts on the Application of Conventions and Recommendations; Articles 19,22 and 35 of the Constitution); Report III, Part 1B (Geneva: ILO, 2016), at 6-8.

${ }^{3}$ The Guardian, 2 November 2015, n.1. According to the Guardian, the findings are based on extensive undercover interviewing and filming in Irish fishing ports as well as worker testimony. They are corroborated by documentary evidence and by interviews with several wellplaced sources.
}

${ }^{4}$ Hereinafter, 'Atypical Scheme' 
employment' not governed by the Employment Permits Acts 2003-20145 and thus constitute a form of regulatory regime for temporary labour migration. Ancillary reforms included the clarification of enforcement powers of the labour inspectorate to facilitate inspection of fishing vessels and the adoption of an inter-agency Memorandum of Understanding between the key enforcement bodies to streamline the effective enforcement of health and safety, marine and employment regulations in the sector.

This package of measures constitutes an attempt to address the vulnerability to labour exploitation of a group of migrant workers primarily through the medium of ordinary employment and immigration regulation, as opposed to a criminal justice approach akin to that adopted in the UK in the Modern Slavery Act 2015, for example. ${ }^{6}$ This article examines the Atypical Scheme as a potential model of good practice for the use of regulation to counteract vulnerability to labour exploitation of migrant workers. More broadly, it considers the dual role of the law in this domain. The legal and institutional framework plays a significant role in creating vulnerability to labour exploitation. Paradoxically, however, legal tools also have the potential to counteract or address this vulnerability. On the question of the appropriate legal tools to counteract vulnerability to labour exploitation among migrant workers, Zou has concluded that neither the international human rights framework nor the trafficking/'modern slavery' discourse, adequately responds to the complex realities of migrants' work relations on a continuum of exploitation. ${ }^{7}$ This article is based on the premise that a focus on protective labour law regulation and enforcement is more likely to respond to these realities.

As the analysis here reveals, the devil is in the detail: industry-appropriate regulation; effective enforcement; and evidence-based policy development are essential to ensure that legal reforms which appear progressive on paper have a real impact on the protection of workers' rights.

\footnotetext{
${ }^{5}$ Information available on the Department of Justice and Equality (Irish Naturalisation \& Immigration Service), http://www.inis.gov.ie/en/INIS/Pages/atypical-working-general (last accessed 13 June 2017).

${ }^{6}$ See J. Haynes, 'The Modern Slavery Act (2015): A Legislative Commentary' (2016) 37 Statute Law Review 33; B. Anderson, 'Migrant Domestic Workers: Good Workers, Poor Slaves, New Connections' (2015) 22 Social Politics 636, in particular at 642-46; C. Robinson, 'Claiming Space for Labour Rights within the United Kingdom Modern Slavery Crusade' (2015) 9 AntiTrafficking Review; J. Fudge, 'The Dangerous Appeal of the Modern Slavery Paradigm', Open Democracy, 2015, https://www.opendemocracy.net/beyondslavery/judy-fudge/dangerous-appealof-modern-slavery-paradigm (last accessed 13 June 2016); Anti-Trafficking Monitoring Group, 'Class Acts? Examining Modern Slavery Legislation Across the UK' (London: ATMG, 2016).

${ }^{7} \mathrm{M}$. Zou, 'The Legal Construction of Hyper-Dependence and Hyper-Precarity in Migrant Work Relations' (2015) 31 International Journal of Comparative Labour Law and Industrial Relations 141.
} 


\section{CREATING AND ADDRESSING VULNERABILITYTO LABOUR EXPLOITATION THROUGH LAW}

A significant body of academic literature has explored the intersection between precarious employment and precarious migration status. ${ }^{8}$ Anderson observes that immigration law controls function as a 'mould', shaping certain types of workers into precarious workers-including through the selection of legal entrants, the enforcement of certain types of employment relations and the creation of 'institutionalised uncertainty'. Through this moulding process, she argues, migrant workers are placed in a position of precarity, their status and situation characterised by instability, lack of protection, insecurity and social and economic vulnerability. ${ }^{10}$ State strategies to address the perceived vulnerabilities of migrant workers usually fail to acknowledge the complicity of immigration controls in producing 'relations of domination and subordination. ${ }^{11}$

In addition to the precarity caused by immigration rules, some groups of migrant workers experience specific gaps in applicable employment protections, in working in sectors which are exempted or excluded from aspects of employment law. For example, the intersecting vulnerabilities of migrant domestic workers - linked to gender, race and socio-economic status - have been well documented, as has the role of immigration law and employment law in creating and perpetuating such vulnerability. ${ }^{12}$ In contrast, the specific experiences of male migrant workers

${ }^{8}$ See, among others, M. Freedland and C. Costello, Migrants at Work: Immigration and Vulnerability in Labour Law (Oxford: Oxford University Press, 2014); E. Albin, 'Introduction: Precarious Work and Human Rights' (2012) 34 Comp Labour L \& Policy J 1; C. Murphy, 'The Enduring Vulnerability of Migrant Domestic Workers in Europe' (2013) 62 ICLQ 599; J. Fudge, 'Precarious Migrant Status and Precarious Employment:The Paradox of International Rights for Migrant Workers' (2012) 34 Comp Labour L \& Policy J 95; B. Anderson, 'Migration, Immigration Controls and the Fashioning of Precarious Workers' (2010) 24 Work, Employment \& Society 300, at 303.

${ }^{9}$ Anderson n.8, at 303.

${ }^{10}$ Ibid. See in particular, Murphy n.8.

${ }^{11}$ B. Anderson, 'Where's the Harm in That? Immigration Enforcement, Trafficking, and the Protection of Migrants' Rights' (2012) 56 American Behavioural Scientist 1241, at 1242.

${ }^{12}$ B. Anderson, Doing the Dirty Work? The Global Politics of Domestic Labour (London: Zed Books, 2000); D. McCann, 'New Frontiers of Regulation: Domestic Work, Working Conditions and the Holistic Assessment of Non-standard Work Norms' (2012-13) 34 Comparative Labour Law \& Policy Journal 167; E. Albin and V. Mantouvalou, 'The ILO Convention on Domestic Workers: From the Shadows to the Light' (2012) 41 ILJ 67; S. Mullally and C. Murphy, 'Migrant Domestic Workers in the UK: Enacting Exemptions, Exclusions, and Rights' (2014) 36 Human Rights Quarterly 397; J. Fudge and K. Strauss, 'Migrants, Unfree Labour, and the Legal Construction of Domestic Servitude: Migrant Domestic Workers in the UK' in M. Freedland and C. Costello (eds), Migrants at Work: Immigration and Vulnerability in Labour Law (Oxford: Oxford University Press, 2014). 
have not yet been explored in as much detail, ${ }^{13}$ and the nexus between employment law and immigration law for those working on sea-fishing vessels has not yet been analysed in scholarly work. In common with migrant workers in other industries, those involved in sea fishing are vulnerable to labour exploitation due to a host of factors, including language barriers; lack of awareness of rights; and difficulties with accessing legal advice and justice in the case of violation of labour rights. ${ }^{14}$

Zou builds on Anderson's work to develop the concepts of 'hyper-dependency'referring to a particular tie of migrant workers to their employers as a requirement of their legal status - and 'hyper-precarity' - referring to the tenuous nature of these workers' entitlements to employment protection, social rights and a secure residence status. This article uses this conceptual framework to analyse the legal approach to migrant workers in the fishing sector in Ireland. Given the relatively recent advent of labour migration into Ireland, the issue of the labour exploitation of migrant workers has only received a significant level of attention in Ireland in recent years..$^{15}$ The rather limited research on labour exploitation of migrant workers to date suggests the existence of a continuum of exploitation, from relatively minor breaches of employment law to trafficking and forced labour. One study conducted by the Migrant Rights Centre of Ireland (MRCI) found that migrant workers in Ireland often suffer from a decent work deficit, with a lack of promotion prospects, no union involvement, precarious hours, lack of avenues for complaint, racial discrimination and harassment. ${ }^{16}$ In 2016, the Low Pay Commission reported that 'There is some evidence to suggest that illegal payment of sub-minimum wages occurs in Ireland and that migrant workers are particularly susceptible, ${ }^{17}$ but that further research is

\footnotetext{
${ }^{13}$ Although see in particular M. Kilkey's work in this field, including 'Men and Domestic Labor: A Missing Link in the Global Care Chain' (2010) 13 Men and Masculinities 126.

${ }^{14}$ Food and Agriculture Organisation of the United Nations, The State of World Fisheries and Aquaculture: Contributing to Food Security and Nutrition for All 2016 (Rome: UNFAO, 2016), at 128.

${ }^{15}$ See, eg, A. Barrett and E. Kelly, The Impact of Ireland's Recession on the Labour Market Outcomes of its Immigrants (ESRI Working Paper Series No. 355, September 2010); Y. O'Connell and F. McGinnity, Immigrants at Work: Ethnicity and Nationality in the Irish Labour Market (Dublin: Equality Authority and Economic and Social Research Institute, 2008); A. Barrett and D. Duffy, Are Ireland's Immigrants Integrating into Its Labour Market? (ESRI Working Paper Series No. 199, June 2007); F. McGinnity and M. Gijsberts, 'A Threat in the Air? Perceptions of Group Discrimination in the First Years After Migration: Comparing Polish Migrants in Germany, the Netherlands, the UK and Ireland' (2016) 4 Ethnicities 290.

${ }^{16}$ See also A. Barrett and Y. McCarthy, 'Immigrants in a Booming Economy: Analysing Their Earnings and Welfare Dependence' (2007) 21 Labour 789; T. Turner, 'The Jobs Immigrants Do: Issues of Displacement and Marginalization in the Irish Labour Market' (2010) 24 Work, Employment and Society 318.

${ }^{17}$ Low Pay Commission, National Recommendations for the Minimum Wage (July 2016), at 46 .
} 
needed in this area. There is also evidence of discrimination against ethnic minority applicants at the recruitment stage. ${ }^{18}$ At the severe end of the continuum, the EU Fundamental Rights Agency has highlighted the prevalence of severe labour exploitation in Ireland and other EU countries. ${ }^{19}$ Working in domestic households was identified as a major risk area for severe labour exploitation in Ireland. ${ }^{20}$

Vulnerability to labour exploitation among migrant workers has been belatedly recognised by the Irish State in recent years, including through legislative initiatives designed to combat human trafficking and forced labour. The Criminal Law (Human Trafficking) (Amendment) Act 2013 criminalises (for the first time) forced labour, within the trafficking framework. ${ }^{21}$ The Employment Permits (Amendment) Act 2014 provided that if a person is undocumented through no fault of their own, they will be able to claim back pay. ${ }^{22}$ There have also been a number of administrative or regulatory initiatives, of which the Atypical Scheme has been the most high profile.

\section{THE LEGAL CONSTRUCTION OFVULNERABILITY AMONG MIGRANT FISHERMEN IN IRELAND PRE-2015}

As mentioned above, it is notoriously difficult to regulate effectively for decent work within the fishing industry, which is seasonal in nature, informal, isolated and hazardous. ${ }^{23}$ In the Irish context prior to 2015 , however, the greater problem was that the employment of non-EEA migrant fishers was effectively taking place in a regulatory vacuum. There were two key legal factors contributing to the vulnerable situation of the workers, pertaining to employment law and immigration law, which resulted in their being trapped in a version of the 'hyper-dependency' and 'hyper-precarity' described by Zou. Their hyper-precarity was rooted in their status as 'share fishermen', an established practice in the industry but one which results in exclusion from protective employment and social welfare frameworks. Share fishermen receive a share of proceeds of a vessel's catch rather than a regular wage. The Irish courts have confirmed on numerous occasions that share fishermen are employed under

${ }^{18} \mathrm{~F}$. McGinnity and J. Lunn, 'Measuring Discrimination Facing Ethnic Minority Job Applicants: An Irish Experiment' (2011) 25 Work, Employment and Society 693.

${ }^{19}$ EU Fundamental Rights Agency, Severe Labour Exploitation: Workers Moving within or into the European Union States' Obligations and Victims' Rights (Vienna: EUFRA, 2015). This term refers to 'all forms of labour exploitation that are criminal under the legislation of the European Union (EU) Member State where the exploitation occurs' and thus covers forced labour, servitude and slavery (EUFRA, at 1).

${ }^{20}$ Ibid., at 53 and 54.

${ }^{21}$ Section 1 of the Criminal Law (Human Trafficking) (Amendment) Act 2013.

${ }^{22}$ Section 4 of the Employment Permits (Amendment) Act 2014.

${ }^{23} \mathrm{UN}$ FAO, op. cit., at 127. 
a contract for service as opposed to a contract of service, meaning that they are not 'employees' protected by employment rights and social insurance frameworks. ${ }^{24}$ The Task Force appeared to view the employment status issue as the single biggest change which could be achieved through regulation. It concluded that the best way to minimise abuses was to ensure that workers were covered by protections afforded to employees. ${ }^{25}$

The hyper-dependency of the workers stemmed not from restrictions attached to their legal status, but rather their lack of any legal status. It seems that most non-EEA workers on Irish fishing boats were undocumented. There was no legal route to migrate to Ireland for the purposes of working on a fishing vessel, which was at odds with the relatively high numbers of non-EEA workers found to be on board. ${ }^{26}$ This follows the pattern in the domestic work sector, for example, whereby low-paid workers are not valued in official immigration policy but are actively sought out by employers - leading to high levels of undocumented work. ${ }^{27}$ Many vessel owners appear to have recruited workers through agencies, by way of the UK. Some insight into this process was provided by the evidence presented to the trial of two vessel owners for work permit and smuggling offences. ${ }^{28}$ The men had arranged with a recruitment agency to hire two workers through the UK and drove from the tip of southern Ireland across the border to collect the men from Belfast to work on their vessels. Neither worker had any form of documents or permission to be in Ireland. The charges were dismissed when the District Court judge concluded that it was unsure whether the vessel owners realised that what they were doing was not in proper compliance with regulations. ${ }^{29}$ An important part of the defence case was that other vessel owners had used the same agency

${ }^{24}$ DPP v McLoughlin [1986] 1 IR 355; Griffin and Deasy v Minister for Social, Community and Family Affairs [2002] 2 ICLMD.

${ }^{25}$ Report of the Government Task Force on Non-EEA Workers in the Irish Fishing Industry, December 2015 (2015), https://www.agriculture.gov.ie/media/migration/publications/2015/ TaskForceReport141215.pdf (last accessed 13 June 2016), at 15. Hereinafter, 'Report of the Task Force?

${ }^{26}$ Ibid., at 6-7.

${ }^{27}$ C. Murphy, 'Enforcing Employment Standards for Undocumented Migrant Domestic Workers in the UK and Ireland: Rethinking Illegality in Zones of Invisibility' (2015) 29 Journal of Immigration, Asylum and Nationality Law 29; A. Triandafyllidou (ed), Irregular Migrant Domestic Workers in Europe: Who Cares? (Aldershot: Ashgate, 2013). On drivers of irregular migration more generally, see S. McKay, 'Transnational Aspects of Undeclared Work and the Role of EU Legislation' (2014) 5 European Journal of Labour Law 116, at 130.

${ }^{28}$ Under the Employment Permits Acts 2003-2014 and section 2 of the Illegal Immigrant (Trafficking) Act 2000.

${ }^{29}$ Judge Dismisses Charges over Illegal Cork Trawler Workers, The Irish Times, 8 March 2017, http://www.irishtimes.com/news/ireland/irish-news/judge-dismisses-charges-over-illegal-corktrawler-workers-1.3002669 (last accessed 13 June 2017). 
and route to recruit workers for a number of years, with the knowledge of at least one government agency. ${ }^{30}$

Undocumented fishermen were thus dependent on the vessel owner in many cases for their job, accommodation and decent working conditions. Pursuing redress for labour law violations would have involved jeopardising all of this and-cruciallyrisking detection and deportation. In any case, as will be discussed further below, it is doubtful whether the workers could have successfully accessed any employment law remedy under Irish law given their undocumented status and the operation of the doctrine of illegality in contract.

\section{ADDRESSING VULNERABILITYTHROUGH REGULATORY REFORMS}

Although reports from a variety of sources suggest that various government departments and state agencies were aware of potential problems within the fishing industry prior to the Guardian exposé in 2015, ${ }^{31}$ the legal and policy response following the report was unusually rapid. A Government Task Force on non-EEA workers in the Irish fishing fleet was convened following a Cabinet decision on 3 November (the very day after the reports), and had concluded its work by December. It was comprised of 16 relevant government departments and state agencies. ${ }^{32}$ Non-governmental stakeholders-fish producer organisations, the International Transport Workers Federation, and the Migrant Rights Centre of Ireland ${ }^{33}$ - were not invited to be full participants in the Task Force and were therefore not involved in deliberating the details of the scheme. Rather, they made short presentations to the Task Force outlining their views on how best to proceed. These diverse stakeholders are of one

30 “'It Was Two Years of Absolute Torment" - Immigration Charges Dismissed Against Two Irish Fishermen Who Hired Filipino Sailors', Irish Independent, 8 March 2017, http://www. independent.ie/irish-news/courts/it-was-two-years-of-absolute-torment-immigration-chargesdismissed-against-two-irish-fishermen-who-hired-filipino-sailors-35513223.html (last accessed 13 June 2017).

${ }^{31}$ The Guardian, 2 November 2015, Part Four: 'An Open Secret'. Also semi-structured interviews carried out by the author with Senator Ged Nash (former Minister of State for Business and Employment, involved in developing the Atypical Scheme in this capacity), 7 June 2017, and with a representative of the Irish Fish Producers Organisation (11 May 2017).

${ }^{32}$ Department of Agriculture Food \& the Marine, Sea Fisheries Protection Authority (SFPA), Bord Iascaigh Mhara (BIM), Department of Jobs, Enterprise \& Innovation (including Workplace Relations Commission), Department of Justice \& Equality (including Irish Naturalisation \& Immigration Service), An Garda Síochána, Attorney General's Office, Department of Defence, Irish Naval Service, Department of Transport, Tourism \& Sport (including Marine Survey Office), Revenue Commissioners, Department of Social Protection, Health \& Safety Authority.

${ }^{33}$ Killybegs Fishermens Organisation, Irish Fish Producers Organisation, Irish South \& West Fish Producers Organisation and Irish South \& East Fish Producers Organisation. 
opinion that this was a missed opportunity in developing a workable and nuanced solution to the problem of labour exploitation in the sector. ${ }^{34}$ This section sets out the key features of the reform undertaken through the Atypical Scheme.

\section{A. Establishing a Comprehensive Regulatory Environment}

The stated aim of the final report of the Task Force was to put in place a 'comprehensive regulatory environment covering all aspects of the employment of non-EEA workers. ${ }^{35}$ To deal with the two-pronged issue of employment status and immigration status, the Task Force proposed a 'holistic approach, ${ }^{36}$ with its centrepiece the atypical scheme of work permits for non-EEA fishermen. As mentioned already, in the Irish system, atypical working schemes are administrative measures which constitute a form of temporary labour migration regime. Under the Atypical Scheme for non-EEA fishermen, the Task Force decided that there would be 512-month permits made available, first to existing members of the fleet and then to external applicants. ${ }^{37}$ The scheme was limited in scope to certain segments of the Irish sea-fishing fleet for vessels above $15 \mathrm{~m}$ in length. ${ }^{38}$

Although the Task Force insisted that this was 'not a question'39 of legalising undocumented workers, in practical terms, for existing workers this was essentially a regularisation scheme-provided that undocumented workers were able to negotiate and obtain a contract of employment. ${ }^{40}$ In order for a permit to be granted, the sea-fishing boat licence holder (employer) had to enter into a contract of employment with the crew member, which would be lodged with the Department of Agriculture, Food and the Marine. The contract of employment would include the right to a safe working environment, regular breaks and rest periods, annual leave and payment of statutory minimum wage, enforceable in Irish law in the usual

\footnotetext{
${ }^{34}$ Semi-structured interviews carried out by the author with the International Transport Workers Federation Co-ordinator for Britain and Ireland ('ITF') (9 May 2016); a representative of Migrant Rights Centre of Ireland (MRCI, 8 June 2017); and a representative of the IFPO (11 May 2017). Hereinafter, 'ITF interview'; 'MRCI interview'; and 'IFPO interview', respectively.

${ }^{35}$ Report of the Task Force, n.25, at 15 .

${ }^{36}$ Ibid., at 16 .

${ }^{37}$ From 1 July 2016, applications for crew members from within the State were no longer accepted. Since then, applications have been accepted only from persons outside of the State. Atypical Permission Scheme for non-EEA Workers on Irish Fishing Vessels: Report of the Risk Profiling and Inspection Group (October 2016, copy on file with the author). Hereinafter, 'Report of the RPIG'.

${ }^{38}$ Polyvalent, Beamer and Specific segments.

${ }^{39}$ Report of the Task Force, n.25, at 15 .

${ }^{40}$ Ibid., at 16.
} 
way. ${ }^{41}$ The licence owner was made directly responsible for the contract of employment, which was required to be certified by a solicitor. ${ }^{42}$ The scheme also specifically clarified that the employer would be responsible for deductions for tax and social insurance contributions. ${ }^{43}$ This constituted a radical shift for vessel owners who, in the main, had little experience of employment regulation. In addition, the Task Force decided that if either the employer or employee breached the contract, the permit would be revoked and no further atypical worker permission would be made granted to the party in breach. ${ }^{44}$

In addition to changing the employment status of migrant fishers, the Atypical Scheme puts in place various mechanisms to formalise the arrangements surrounding the employment of migrant fishers. At the recruitment stage, the certified contract of employment must be in place before the worker travels to Ireland (for those applying from outside the country). ${ }^{45}$ Employers must also provide evidence of adequate healthcare coverage for all such employees. ${ }^{46} \mathrm{~A}$ depository of contracts was established, which would allow them to be shared with the relevant regulatory bodies. ${ }^{47}$ The pre-approval application process involves the provision of a range of documentation to the central depository in addition to the contract of employment. ${ }^{48}$ In order to avail of the scheme, employers are thus required to voluntarily subject themselves to a level of scrutiny, formality and regulation that was previously nonexistent in respect of work performed on board the vessel. For their part, the crew member is required to carry relevant documentation at all times within the State to facilitate inspection. ${ }^{49}$

\section{B. Freedom to Change Employer}

One of the criticisms levelled at temporary labour migration schemes is that temporary migration often statuses tie the worker to the employer. This has been a central aspect of the debate on the overseas domestic workers visa in the UK, for example. ${ }^{50}$ The Atypical Scheme does not impose such a condition: a crew member may enter

${ }^{41}$ Ibid., at 18, Atypical Scheme (annexed to the Report of the Task Force). The contract template (minimum conditions) is outlined at $\mathrm{p} 22$ of the scheme.

${ }^{42}$ Atypical Scheme, para 9. The requirement for the direct employment relationship was included to eliminate the involvement of recruitment agencies in the employment relationship.

${ }^{43}$ Ibid., para 7.

${ }^{44}$ Ibid., paras 15 and 16.

${ }^{45}$ Ibid., para 17.

${ }^{46}$ Ibid., para 22.

${ }^{47}$ Ibid., para 9.

${ }^{48}$ As detailed in Report of the Task Force, n.25, at 21.

${ }^{49}$ Atypical Scheme, para 12.

${ }^{50}$ See V. Mantouvalou, 'Am I Free Yet? Overseas Domestic Workers in Slavery' (2015) 42 Journal of Law and Society 329. 
a new contract of employment with another employer, with any change subject to the same conditions as a new application under the scheme. However, the worker is still in a position of dependency and subordination vis-à-vis the employer. In practical terms, as the employment permit is granted to an individual employer rather than for the fishing sector, in order to change employer the worker would need to convince a new employer to go through the formalities described above in order to obtain a new contract of employment with them. In addition, in a relatively small industry in which the employers are well networked, ${ }^{51}$ employees who raise labour law issues may find it difficult to gain alternative employment in the sector. ${ }^{52}$ The experience of MRCI in assisting workers (through outreach activities and drop-in centres) is that the freedom to change employer is too difficult to exercise in practice and that the rules of the scheme still do not sufficiently empower the employee to demand decent working conditions. ${ }^{53}$

\section{Enhancing Enforcement through Co-operation and Development of New Inspection Protocols}

Enhancing the effective enforcement of employment and health and safety rights was identified as a key plank of the reforms by the Task Force, which outlined that cooperation would be underpinned by an inter-agency Memorandum of Understanding (MoU). The MoU provides for information exchange among the multiple enforcement bodies involved, including labour inspectors, immigration services, health and safety bodies and maritime regulatory authorities. The MoU is intended to underpin a 'coherent and transparent cross-Government approach'54 to the monitoring of statutory requirements relating to non-EEA workers on board Irish fishing vessels.

The Workplace Relations Commission ('WRC') is the main labour inspection body in Ireland and is empowered to enter vessels under the Workplace Relations Commission Act 2015.55 The labour inspectorate had scant experience with examining fishing vessels prior to 2016, given that most people working on board such vessels were share fishermen and outside their inspection remit. ${ }^{56}$ In the first quarter of 2016, the WRC engaged in

\footnotetext{
${ }^{51}$ In the trial discussed above, the court room was packed with fishermen expressing their anger that the criminal charges were being pursued against the vessel owners.

${ }^{52} \mathrm{MRCI}$ interview, n.34.

${ }^{53}$ Ibid.

${ }^{54}$ 'Memorandum of Understanding for the Monitoring and Enforcement of the Terms of Employment of non-EEA Crewmen in Parts of the Irish Sea Fishing Fleet Pursuant to the Establishment of the Atypical Work Permission Scheme' (copy on file with the author), at 6.

${ }^{55}$ Section 27 of the Workplace Relations Commission Act 2015, which specifically states at s 27(8) that 'premises' includes a 'vehicle, vessel, ship and railway carriage'.

${ }^{56}$ Any action prior to 2015 was complaint-driven. Semi-structured interview conducted by the author with a representative of the WRC, 30 May 2016 ('WRC interview').
} 
information and awareness dissemination to make vessel owners aware of their new obligations in relation to fishermen with Atypical Scheme work permits. ${ }^{57}$ It also embarked on a programme of inspecting all vessels which potentially fell within the scheme. ${ }^{58}$

The WRC has found it necessary to adapt its usual inspection protocols in line with the specificity of the fishing sector. One of the key challenges is 'finding' vessels which move around frequently, and to this end, a satellite tracking app is used to locate particular vessels. ${ }^{59}$ The first phase of inspections has been on vessels moored at harbour, and inspectors have actively used complementary surveillance (whereby inspectors would observe who is coming and going from vessels) to try to identify crew members. ${ }^{60}$ In addition, the WRC has developed a system of risk profiling to identify which boats should be inspected and re-inspected..$^{61}$ There is no doubt that these measures constitute a genuine attempt to get to grips with the challenging environment of the fishing industry, within a relatively short space of time. However, as will be seen below, the effectiveness of the inspection regime in preventing exploitation is hotly contested.

\section{THEATYPICAL SCHEME: MODEL OF GOOD PRACTICE OR MISSED OPPORTUNITY?}

Have the Atypical Scheme and complementary reforms achieved the aim of the Task Force to 'minimise' the risk of exploitation while also 'ensuring that reputable employers are able to recruit trained and experienced crew members'? Unfortunately, defects in the design of the scheme and difficulties with enforcement have meant that neither of these objectives has been met. This section suggests that the lack of a fully researched evidence base for the measures adopted, and the development of the scheme without comprehensive input from stakeholders, are at the root of some of the problems identified.

\section{A. LowTake-up of Work Permits}

The most striking outcome of the reform process has been the low take-up of the scheme among workers already in the State. Of the 500 available permits (which both workers' and fish producers' organisations had thought would be too few), ${ }^{62}$ just 196

\footnotetext{
${ }^{57}$ WRC interview, n.56.

${ }^{58}$ Ibid.

${ }^{59}$ Ibid.

${ }^{60}$ Ibid.

${ }^{61}$ Ibid. and Report of the RPIG, n.37.

${ }^{62}$ 'Calls for Ireland to Double Number of Permits to Protect Migrant Fishermen', Guardian, 23 November 2015, available at https:/www.theguardian.com/global-development/2015/ nov/23/irish-fishing-industry-calls-for-ireland-double-number-permits-issued-migrant-fishermen (last accessed 13 June 2017).
} 
were issued to the end of May 2017.63 Of these 196 permits, 32 were revoked and 42 have been renewed to date. ${ }^{64}$ The reasons for this are difficult to assess. The International Transport Workers Federation Co-ordinator for Britain and Ireland ('ITF') maintains that some employers simply do not want to sign up to a contract of employment and a work permit as that means that they would have to pay minimum wage to the workers all year round. ${ }^{65} \mathrm{MRCI}$ has also noted that their experience on the ground has been that some employers did not want to engage with the levels of formality attached to participating in the scheme, or the expense involved with solicitors' fees. ${ }^{66}$ This resulted the dismissal of some fishermen, and also a lack of interest in renewing work permits for a second year. ${ }^{67}$ A lack of information on the Atypical Scheme for fishermen themselves, made available in their own language, was also a factor, in MRCI's view. ${ }^{68}$

One common theme identified by all non-governmental stakeholders is the awkward fit of the employer-employee relationship with the traditional share fishing model. The transition to an employment relationship was seen by government as a key means to ensure better regulation of the conditions of migrant workers, however in practice it has caused difficulties. The Irish Fish Producer's Organisation ('IFPO') is of the view that the scheme has not been popular because the move to make migrant workers employees (rather than share fishermen) is at odds with the long-standing structure of the industry and results in a two-tier system among crew members. When income from the catch is low, the Irish and EU crew members on board resent that migrant workers are entitled to be paid minimum wage in any event. ${ }^{69}$ When the catch is good, the migrant workers are disadvantaged as they earn less than others doing the same work. ${ }^{70}$ The inequality that this creates on board is problematic for vessel owners.

Anecdotal evidence suggests that the low take-up of work permits has meant that more EU workers are now being employed instead of non-EEA workers. ${ }^{71}$ However, there are other potential explanations and consequences. The Risk Profiling and Inspection Group ('RPIG'), formed after the work of the Task Force had completed, ${ }^{72}$ noted that ${ }^{~} i t$ is possible that there has been a shift of workers from

\footnotetext{
${ }^{63}$ Statistics provided by WRC, on file with the author.

${ }^{64}$ Statistics provided by WRC, on file with the author. The author requested further information from the Department of Justice and Equality on these figures, and the reasons for revocation, however, there has been no response to date.

${ }^{65}$ ITF interview, n.34.

${ }^{6} \mathrm{MRCI}$ interview, n.34.

${ }^{67}$ Ibid.

${ }^{68}$ Ibid.

${ }^{69}$ IFPO interview, n.34.

${ }^{70}$ Report of the RPIG, n.37, at 10 .

${ }^{71}$ Ibid., at 10.

${ }^{72}$ Its membership comprised the Workplace Relations Commission; An Garda Síochána; BIM; Department of Jobs, Enterprise \& Innovation: Department of Justice \& Equality/Irish Naturalisation and Immigration Service; Department of Transport, Tourism \& Sport/Marine
} 
vessels of 15 metres and more to vessels of shorter length ${ }^{73}$ and recommended that consideration should be given to extending the Scheme to smaller vessels. ${ }^{74}$ More worryingly, the Group cited evidence of ongoing 'off scheme' recruitment campaigns aimed at attracting non-EEA workers and offering terms and conditions inferior to those enjoyed by employees required under the Scheme. ${ }^{75}$ The Group notes that rigorous monitoring of the Scheme, targeted inspections and an information campaign for agencies and workers in the country of origin is the most effective strategy to counteract this ongoing informal recruitment.

\section{B. Continuing Breaches of Employment Standards?}

The inspections to date of boats falling within the scope of the Scheme have shown that contraventions of both employment law and immigration law remain a feature of this sector. The inspection of 141 vessels revealed 196 contraventions, including 30 cases of undocumented workers, 15 breaches of the Atypical Scheme and 72 instances in which no employment records were kept. ${ }^{76}$ While these figures show that the level of non-compliance is high, it is difficult to discern the true level of severity of employment law breaches from the work of the WRC. Pay rate contraventions were found in only two cases and only eight cases of problems with annual leave were detected, for example. Sunday compensation was an issue in 17 cases. In addition, a joint operation undertaken between the WRC and the police, involving 40 vessels, uncovered 'no evidence of human trafficking or labour exploitation...in any location'.77

These findings are at odds with the views of those involved with the workers on an ongoing basis, who believe that conditions have not significantly improved since 2015. ${ }^{78} \mathrm{MRCI}$, the ITF and Senator Ged Nash ${ }^{79}$ all report that conditions may in fact be worsening for some individuals, even where they have been regularised through

Survey Office; Department of Defence/Naval Service; Health and Safety Authority; Office of the Revenue Commissioners; Sea Fisheries Protection Authority; Workplace Relations Commission; Department of Agriculture, Food and the Marine.

${ }^{73}$ Report of the RPIG, n.37, at 13.

${ }^{74}$ Ibid., at 13 .

${ }^{75}$ Ibid., at 13 .

${ }^{76}$ Statistics obtained from the WRC, on file with the author.

${ }^{77}$ Frances Fitzgerald (Minister for Justice and Equality), written answers to parliamentary questions [37687/16], 16 December 2016.

${ }^{78}$ See concerns raised by Senator Ged Nash in the Irish Senate. Seanad Debates, 8 February 2017. See also 'Scheme for Fishing Crews is Legitimising Slavery', The Irish Times, 7 February 2017. http://www.irishtimes.com/news/ireland/irish-news/scheme-for-fishing-crews-is-legitimising-slavery-1.2965818 (last accessed 13 June 2017).

${ }^{79}$ Former Minister of State for Business and Employment, involved in developing the Atypical Scheme. 
the scheme-most importantly by their wages going down as a result of the transition from share fisherman to employee. ${ }^{80}$ This tallies with the Guardian's updated findings that some workers are now receiving minimum wage for a 39-hour week, even when working a much longer week - sometimes up to 100 hours. ${ }^{81}$ So what are the reasons for these discrepancies and the possible lack of detection by the enforcement bodies?

\section{Fragmented, Limited Enforcement?}

The responsibility for enforcing health and safety, employment and immigration regulation in the fishing sector is highly fragmented among a variety of government departments, law enforcement, the defence forces and regulatory bodies. ${ }^{82}$ While the MoU has formalised and enhanced co-operation, the fragmented responsibility makes it difficult for any one body to ascertain a full picture of the conditions on board fishing vessels. This point is clearly illustrated by the division of responsibility in respect of minimum wage and working time compliance. While the WRC's responsibilities relate to the enforcement of employment rights legislation, including minimum wage legislation, ${ }^{83}$ the Marine Survey Office ('MSO') ${ }^{84}$ is responsible for enforcing legislation relating to the rest periods and maximum working time provisions for sea fishermen. ${ }^{85}$ To date, there has been no official co-operation between or joint inspections involving the WRC and the MSO since the signing of the MoU. The separation of responsibility relating to payment for working hours on the one hand and rest periods on the other hand creates an information gap for WRC inspectors in their assessment of compliance with the minimum wage rules. This technical enforcement point thus potentially undermines the effectiveness of the basic protection of the right to be paid set out in the scheme.

More generally, the inspection work of the WRC is limited both in scope and method. In addition to the working time/rest time issue outlined above, the WRC does not have jurisdiction to directly assess the living conditions of migrant workers (which also belongs to the MSO), or investigate situations of harassment or

${ }^{80} \mathrm{MRCI}$ interview, n.34; ITF interview, n.34; and Ged Nash interview, n.31.

${ }^{81}$ 'Irish Trawlers Accused of Alarming Abuses of Migrant Workers', Guardian, 8 February 2017. https://www.theguardian.com/global-development/2017/feb/08/irish-trawlers-abusesmigrant-workers (last accessed 13 June 2016).

${ }^{82}$ Inspections can be carried out by the police, the Naval Service, the Health and Safety Authority, the Marine Survey Office and the Workplace Relations Commission.

${ }^{83}$ Most importantly, the Terms of Employment (Information) Act 1994; Organisation of Working Time Act 1997; and the National Minimum Wage Acts 2000 and 2015.

${ }^{84}$ Based within the Department of Tourism, Transport and Sport.

${ }^{85}$ European Communities (Workers on Board Sea-Going Fishing Vessels) (Organisation of Working Time) Regulations 2003 (S.I. No. 709/2003). The MoU specifically states (at 5): 'WRC inspectors are not authorised officers under the legislation and have no role in its enforcement' 
discrimination which go beyond the statutory functions of the WRC. In addition, the WRC's method of inspection is largely based on records kept (or not kept, as the case may be) by the vessel owner. ${ }^{86}$ Crew members are also interviewed (where possible, in private away from the vessel), and as noted above the WRC also carries out surveillance. ${ }^{87}$ However, records, interviews and surveillance on land may not give an accurate picture of what is actually happening on the vessel out at sea. This is particularly the case where records are very deficient or where fishermen have poor English and no interpreter is provided. Identifying the actual crew members of the vessel when boarding at harbours can be problematic, as can the lack of knowledge about when a particular boat may land. ${ }^{88}$ The next phase of the WRC inspections will involve inspections at sea, ${ }^{89}$ which may help to address some of these issues.

Finally, the ITF and MRCI have criticised the 'voluntary compliance' approach adopted by the WRC. When asked to report on the continuing serious allegations of illegal pay and conditions for workers in the fishing industry, the Minister for Jobs, Enterprise and Innovation noted that 'Employers/Vessel Owners are afforded all reasonable opportunity to rectify contraventions and, where relevant, pay any unpaid wages and/or make good on entitlements arising from these contraventions. ${ }^{90}$ Compliance notices or legal proceedings will only be initiated where an employer has failed or is unwilling to effect compliance. ${ }^{91}$ MRCI suggests that this is inadequate to address the level of non-compliance in the industry and that harsher measures, such as depriving the boat owner of their fishing licence for example, should have been considered..$^{92}$ However, the voluntary compliance approach is the established practice of the WRC across all sectors, and there was no suggestion in the work of the Task Force that this should be adapted for the fishing industry.

\section{The Broader Context: Overlap of Immigration and Employment Enforcement}

One of the most important barriers to achieving a protective regulatory environment for migrant fishermen is not unique to the fishing sector, and comes back to the age-old problem of the legal interaction of immigration and employment frameworks. While international commentary has identified that a firewall between employment inspectors and immigration authorities is the most effective

${ }^{86}$ Workplace Relations Commission, Annual Report 2016, at 24.

${ }^{87}$ Ibid.; also WRC interview, n.56.

${ }^{88}$ Report of the RPIG, n.37, at 10-11.

${ }^{89}$ WRC interview, n.56.

${ }^{90}$ Mary Mitchell O'Connor (Minister for Minister for Jobs, Enterprise and Innovation), written answers to parliamentary questions [9355/17], 23 February 2017.

${ }^{91}$ Ibid.

${ }^{92}$ MRCI interview, n.34. 
way to ensure that fear of deportation does not hinder migrant workers in claiming their labour rights, ${ }^{93}$ immigration and employment enforcement are completely intertwined in the Irish context. The WRC has enforcement functions under the Employment Permits Acts 2003-2014, and as such is an extension of the immigration authorities. It is not the policy of the WRC to prosecute undocumented employees for breach of the Acts. ${ }^{94}$ However, an inspector might 'issue a direction to a worker to immediately cease work' where a non-EEA worker is detected with no permission to work. ${ }^{95}$ Even more significantly, if they find an undocumented person on board they would share that information with the Irish Naturalisation and Immigration Service (in accordance with the $\mathrm{MoU}$ ) ${ }^{96}$ and that person could ultimately be deported.

In order to detect and pursue violations of minimum wage legislation in particular, the WRC and other bodies would require the co-operation of and statements from crew on board. However, migrant workers are likely to fear either losing their work permit, not having their work permit renewed, or being deported if detected while undocumented. The Risk Profiling and Inspection Group itself acknowledges that the enhanced co-operation on foot of the MoU probably has the unintended consequence that unauthorised workers may not participate in safety training for fear of being detected by other agencies. ${ }^{97}$

A related problem is that, aside from their deportability, undocumented workers remain excluded from employment protections under Irish law. The question of the enforceability of employment law by undocumented workers was raised for the first time in Ireland in Hussein $v$ The Labour Court, ${ }^{98}$ which was ultimately decided by the Supreme Court. In Ireland, as in the UK, ${ }^{99}$ this is a thorny issue as the doctrine of illegality in contract means that the underlying contract of employment is tainted by the illegal work and invalid, thus meaning that the worker is not an 'employee' for

\footnotetext{
${ }^{93}$ See the recommendations of the EU Fundamental Rights Agency ('EUFRA'), Migrants in an Irregular Situation Employed in Domestic Work: Fundamental Rights Challenges for the European Union and Its Member States (EUFRA, July 2011), at 45. See generally, G. Noll, 'The Laws of Undocumented Migration' (2010) 12 European Journal of Migration and Law 143.

${ }^{94}$ WRC interview, n.56.

${ }^{95}$ Report of the RPIG, n.37, at 6 .

${ }^{96} \mathrm{MoU}, \mathrm{n} .54$, at 8.

${ }^{97}$ Report of the RPIG, n.37, at 11.

${ }^{98}$ Hussein v The Labour Court [2012] IEHC 364; [2015] IESC 58.

${ }^{99}$ For a recent commentary in the UK (although with a focus on illegality in tort rather than contract), see M. Zou and J. Goudkamp, 'Hounga v Allen' (2015) 29 Journal of Immigration, Asylum and Nationality Law 56; J. Goudkamp and M. Zou, 'The Defence of Illegality in Tort: Beyond Judicial Redemption?' (2015) 74 Cambridge Law Journal 13; A. Bogg and S. Green, 'Rights Are Not Just for the Virtuous: What Hounga Means for the Illegality Defence in the Discrimination Torts' (2015) 44 ILJ 101; and A. Bogg and T. Novitz, 'Race Discrimination and the Doctrine of Illegality' (2013) 129 Law Quarterly Review 12.
} 
the purposes of employment law. ${ }^{100}$ The current position in Ireland is that undocumented workers cannot generally enforce employment rights, although there were some obiter dicta comments in the Supreme Court to the effect that this might be reviewed in the appropriate case, in light of the principle of proportionality. ${ }^{101}$

In summary, the protective impact of an individual measure such as the Atypical Scheme is limited in the broader context of a system which does not segregate employment and immigration enforcement, and in which undocumented workers are almost completely unprotected by employment standards.

\section{CONCLUSIONS}

Overall, the reforms examined in this article display some elements of good practice in terms of regulating to counteract labour exploitation among temporary migrant workers. In particular, the freedom in principle of an employee to move employer, the system of risk profiling of vessels and the concerted campaign of labour inspections of fishing vessels are to be welcomed.

The analysis has also shown, however, that despite these positive features, the reforms have not, in practice, addressed the problems of the hyper-dependence and hyper-precarity of migrant workers in the sea-fishing fleet. The difficulties caused by the imposition of an employment relationship for non-EEA crew members, in the situation where other workers on the same vessel would remain share fishermen, is one consequence of a lack of thorough consultation with non-governmental stakeholders with in-depth knowledge of the industry. Moreover, the lack of detection of pay rate contraventions, and of severe forms of labour exploitation, as well as evidence of continuing off-scheme recruitment, raise questions about the adequacy of existing means of enforcement.

Fundamentally, the specific measures outlined in this article do not displace the deeper causes of vulnerability of migrants in the workplace: the inextricable link between immigration status and enforceability of employment standards; the intertwinement of immigration and employment enforcement regimes; and dependency on the employer for a temporary migration status. Individual regulatory measures will continue to have a limited impact unless the state acknowledges and addresses

\footnotetext{
${ }^{100}$ See generally, Murphy n.27; E. Dewhurst, 'Models of Protection of the Right of Irregular Immigrants to Back Pay: The Impact of the Interconnection between Immigration Law and Labor Law' (2013) 35 Comparative Labor Law and Policy Journal 101; E. Dewhurst, 'The Gap between Immigration and Employment Law in Ireland: Irregular Immigrants Fall through the Cracks' (2013) 10 Irish Journal of Employment Law 11; E. Dewhurst, 'The Denial of Labour Rights to Irregular Immigrants under Irish Labour Law' (2012) 4 European Journal of Labour Law 300 .

${ }^{101}$ Hussein v The Labour Court [2012] IEHC 364, para 52, per Murray J.
} 
the imbalance in the power relations between the employer and employee which is produced by these factors.

CLÍODHNA MURPHY

Maynooth University

email: cliodhna.murphy@nuim.ie

doi:10.1093/indlaw/dwx016 